\title{
RURAL DECENTRALIZATION IN INDIA AT THE CROSS- ROADS: THE CONTEXT, CHALLENGES AND CONSEQUENCES
}

\author{
Prabhat Kumar Datta
}

Institute of Development Studies Kolkata (Funded by the Government of West Bengal as a Centre of Excellence in Social Sciences), India.

E-mail: dattaprabhat@gmail.com

Citation: Datta, P.K. 2019. Rural Decentralization in India at the Cross-roads: The Context, Challenges and Consequences. J. Asian Rur. Stud. 3(1): 17-34

\begin{abstract}
This article attempts to make a critical evaluation of the working of the institutional system of democratic decentralization in rural India against the backdrop of its historical development. It has been argued that although it is not difficult to trace the roots of decentralized government in ancient India it hardly resembles the modern model of decentralization conceived and developed by a host of the Western scholars. The colonial rulers introduced decentralized governance in India to promote colonial objectives and to help perpetuate the British rule. The post- colonial state took steps to initiate the process of rural decentralization in 1950s but it went out of steam soon. In 1990s there was a paradigm shift in India's policy. And in 1992 the Constitution was amended to pave the road for democratic decentralization but currently it seems to be in the cross-roads. This paper seeks to capture the historical development of the journey of decentralization and identify the roadblocks and the takeaways from the experience of working of the institutions of rural decentralization in India.
\end{abstract}

Keywords: Decentralization; Self-government; Constitutional amendment; Political will; Funds and functionaries; Parallel bodies

\section{Introduction}

One of the most popular state forms that has opened spaces for a wider and deeper participation of citizens at the local level, is decentralization. It is this participative dimension which constitutes one of the basic pillars of good governance. The concept of good governance popularized by the World Bank for the purpose of ensuring loan repayment in sub-Saharan Africa focusing principally on management undermining politics, has undergone fundamental change over the last few decades It is now widely accepted as a new concept in governance with emphasis on decentralization, participation, transparency, civil society engagement and the like.

Significantly, decentralization has got unprecedented momentum in the developing countries in 1990's which was also coincided with the increasing acceptance of the of neo-liberal policy in the developing countries at the instance of the international financial organizations like the World Bank. However, in all but 12 of the 75 developing countries' more than five million people have implemented some form of decentralization. Parallel to these developments, enabling legal frameworks and 
institutional channels for citizen participation at the local level have been developed in many of these countries, as shown below:

$\begin{array}{ll}\text { Legal Enabling Environment for People's Participation } \\ \text { Philippines } & : \text { Local Government Code (1990) } \\ \text { India } & : 73^{\text {rd }} \text { and } 74^{\text {th }} \text { Constitutional Amendments (1993-94) } \\ \text { Honduras } & : \text { Municipal Law (1990) } \\ \text { Bolivia } & : \text { Popular Participation Law (1992) } \\ \text { Namibia } & \text { : Local Authority Act (1992) } \\ \text { Uganda } & \text { : Local Government Act (1997) } \\ \text { Tanzania } & : \text { Local Authorities Act (1992) }\end{array}$

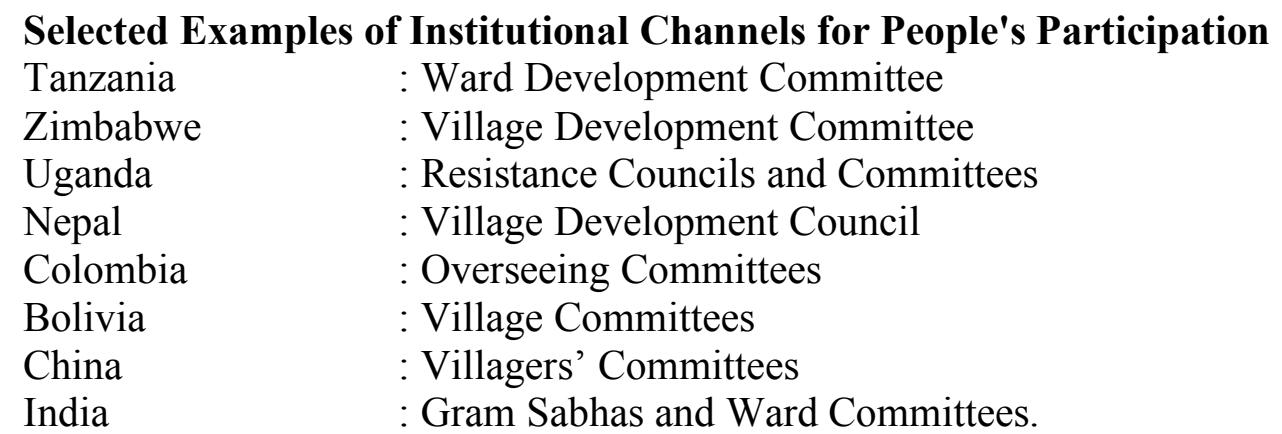

It may be recalled that that decentralization as a politico-administrative mechanism for the expansion of the base of democracy found itself manifested in the form of local government. It gathered momentum in Europe in the first half of the nineteenth century when inadequacies of the existing democratic government came to light, thanks to the contribution of the enlightened scholars and activists. The liberal school of thought felt that the institutions of local self-government need to be developed primarily for effecting improvement in administration, ensuring participation of the citizens in the processes of governance, protecting individual liberty and training the citizens in the art of the democratic government. According to Tocqueville, for example, town meetings are to liberty what primary schools are to science; they bring it within the people's reach, they teach how to use and how to enjoy. John Stuart Mill stressed the educative function of the local government for securing twin benefits to the nation, namely: provision of a democratic training ground for the 19 the century town and country gentlemen in the local bodies some of whom might eventually be called upon to perform duties of national importance in Parliament and education for the broader electorate in the complicated task of exercising choices in matters of elections of representatives and allocation of resources Bryce concurred with Mill in the virtues of local government institutions resulting from division of labor, political education and community of interests. Local institutions, he felt train men not only to work for others but also to work effectively with others (Bryce, 1983, quoted in Mutalib et al., 2002). 


\section{The Ancient Tradition of Local Governance in India}

The self-governing village communities had existed in India from the earliest times as is evident from their reference to the Rig Veda the origin of which can be traced back to $1200 \mathrm{BC}$. The village sabhas (village assemblies) and Gramins (senior persons of the village) used to act as links between the villagers and the higher authorities. In course of time these village bodies came to be known as the panchayats which remained unchanged even during mediaeval and Mughal period despite the fact the their judicial powers were reduced.

\section{The Colonial Perspective of Local Governance}

The administrative system in India broke down almost completely on the eve of the colonial rule. This was why the colonial government had to pass through "long and weary experiments in order to develop a sound administrative system" (Bhattarcharya and Datta, 1991). It was in the last phase of the rule of the East India Company and in the period immediately following the establishment of the direct rule of the Crown that consideration was paid, though in a small scale, to the supply of the services like health, sanitation, education, roads and the like. This need was highlighted by the Report of the Royal Army Sanitation, 1863.

The Sepoy Mutiny caused a significant shift in the political perspective of the colonial rulers. Andrew Laing, member (Finance) of the Viceroy's Council observed that the revolt of 1857 had put imperial finances under considerable strain and it was necessary to finance local services out of local taxation. Lord Lawrence, another member of the Viceroy's Council, came out with resolutions emphasizing that Indians are capable of governing their local affairs themselves and the village communities were the most abiding of India's institutions. They suggested that local services should be financed out of local taxes. Lord Mayo's Resolution of 1874 led to the birth of local self-government in the villages primarily to harness local interest, supervision and care for the management of funds devoted to education, sanitation, medical charity and public works.

The growing industrial and commercial needs of the people of India and obligations towards the people perceived in liberal terms worsened the situation as it put pressure on the budgetary resources. The other important compulsions included fuller political and economic integration, need for building reliable information system extending right up to the villages because even after the Sepoy Mutiny there were sporadic peasant movements throughout the country and the need for recruiting new set of collaborators in the countryside apart from the existing zamindars. These collaborators represented big intermediaries, traders-cum-merchants and moneylenders who were becoming economically strong due to commercialization of agriculture. Their strength grew further following their being a part of the local governance system. One must also keep in mind that it was the time of the imperial expansion outside India characterized by the imperialist wars in different parts of Asia. And the charges for these were borne out of the Indian exchequer. Growing freedom movement posed a very serious threat to the colonial rule and decentralization in the form of local government was conceived as an institutional arrangement for the co-option of a section of the freedom fighters. 


\section{Ripon's Seminal Contribution}

The idea of local self-government received a remarkable turn in 1882 when Lord Ripon came out with his famous resolution which is regarded as the Magna Charta of the local democracy in India during the days of the colonial rule. He was the first to suggest that it was not primarily for effecting improvement in administration that local government has to be promoted. He argued that political education and administrative efficiency needed to be put into the perspective. He was interested in reviving and extending the indigenous system and to making "full use of what remains of the village system" (Wolf, 1921).

The most remarkable innovation proposed by Ripon was the establishment of a network of rural local bodies-six years before there were any such Councils in England" (Tinker, 1968). Ripon's proposals were given warm welcome by that stratum of society which was active in politics, namely, S.N. Banerjea, G.K. Gokhale. But he was unsuccessful in implementing his scheme. The District Boards met very infrequently. The landlord-members did not attend the meetings as they could not follow the unfamiliar procedure. A small group of lawyers could follow but they were not allowed to speak. Added to it was the social scenario of the villages which came under the control of the local daroga (police) and the bania (money lenders) The Government of India did not extend necessary support.

But the fact remains that Ripon was the first to emphasize that the legitimate aspirations of the westernized intelligentsia had to be satisfied not only through preponderant non-official majorities in the local bodies but also through the grant of the right to elect their chairman and whatever control the government had to exercise over local bodies, should be exercised from without, not from within. His liberalism drawing inspiration from Hume coupled with his understanding of the need for providing outlet to the westernized middle class helped him conceptualize local government not merely as instruments of effecting improvement in administration but also as instruments of popular and political education of the masses.

\section{Some Positive Initiatives}

True it is that the progress of local government on the lines of Ripon was insignificant but the fact remains that idea of local self- government as developed in Europe had gained currency and was accepted by the vanguard of the freedom struggle, Indian National Congress as the political ideal for the country in 1906. The Royal Commission on Decentralization (1907) recommended the constitution and development of village panchayats for the administration of the village affairs. But as in the case of the Ripon's resolution, the recommendations of the Royal Commission on Decentralization remained on paper for which the Indian National Congress blamed the "inefficient bureaucracy".

Against this backdrop came the Montague-Chelmsford Reforms Act of Act of 1919 in terms of which local government became a transferred subject. Although it meant transfer of the local government to the hands of the Indian ministers in the provinces local government could not emerge as democratic and vibrant instruments of selfgovernment at the village level. Till about 1920 local bodies were practically consultative bodies set up by the provincial governments to help them in administering 
local affairs. The concept of local government as the agent of the higher level government practiced by the colonial rulers remained the guiding premise of local governance in colonial India. Incidentally, the freedom movement led by Gandhi accepted decentralization as the foundation of rural democracy in India. Gandhi talked to village swaraj and felt that the villages should be starting point of India's democratic governance.

However, the so-called democratization during the colonial rule was very limited because the franchise was restricted to local magnates and their cohorts. Secondly, the local government institutions set up by the colonial rulers were imposed from the above and as Bandypadhayay and others observe, remained loosely grafted to the indigenous rural society. They rightly observe that the old community based self-governing institutions and the newly created and superimposed bodies of local government failed to develop any creative relationship.

\section{The Rise of the First Generation Panchaytai Raj}

Strikingly, the post-colonial India failed to make significant and visible break with colonial past despite tall promises at the time of the nationalist movement and Gandhi's insistence on village swaraj as the starting point of India's democracy. The architects of the Constitution were primarily concerned about the unity and integrity of the country and the trauma of partition created necessary objective conditions to plead for it. This led to a situation where the colonial model of federalism with strong unitary bias was accepted for the country choking the rise and growth of liberal democratic local selfgoverning institutions in India. There was no mention about the panchayati raj in the objective resolutions presented before the Constituent Assembly. The chairman of the Drafting Committee, Dr. B.R. Ambedkar was opposed to the empowerment of the village panchayats presumably because of his unhappy personal experience in the villages in the early years of his life. He said in the Constituent Assembly, to quote, "Indian villages are sinks of localism, ignorance, narrow mindedness and communalism -------." (Association of Voluntary Agencies for Rural Development, 1966).

A close study of the background leading to the rise of the first generation panchayati raj in India in late 1950s clearly indicates that there was unavoidable political compulsion at the end of the ruling party. The leaders of the Indian National Congress realized that as the freedom movement had a strong urban bias, rural people who stayed away from the mainstream, needed to be roped in through institutional mechanism for the consolidation of the political strength of the party. The ruling class had also felt the need for enlisting participation of the rural people in the implementation of the development programs conceived and directed from the center and through this, winning their political support. The first initiative in the form of the Community Development Program for the active involvement of the community in the implementation of the rural development programs, failed to evoke people's initiative because the program was imposed from the top and there were no democratic structures to enlist participation of the community. This gave birth to the first generation panchayati raj in India on the basis of the recommendations of the Balvantray Mehta Committee report. There were internal contradictions because the attempt was made to involve people without replacing the strong colonial bureaucratic structures by the democratic structures. Added to it was the highly centralized governing system of the 
country initially created by the constitution and subsequently promoted by the hegemonic rule of the Congress. The three -tiered institutional structures created had faced challenges from within as it helped develop new centers of power leading to 'cooling off of enthusiasm of the members of Parliament'. The first generation panchaytai raj system collapsed in all states except Mahasrastra and Gujarat soon after Nehru's death in 1964.

\section{The Journey of the Second Generation Panchayats}

The transfer of political power from the hands of the Indian National Congress to the coalition of several opposition parties in New Delhi in 1977 brought about a change in the national political atmosphere. The new government took steps to regenerate the stagnant panchayati raj for which they appointed a committee under the leadership of Asoka Mehta which submitted report in 1978. The Committee conceptualized panchayats in a more practical manner. It stressed the need for participation of political parties and felt the need for amending the constitution as an important step towards strengthening PRIs but the Government was very short-lived. Only three states, namely, Karnataka, Andhra Pradesh and West Bengal ruled by the regionally based political parties partly accepted the recommendations of the Committee. They had established and empowered village panchayats. But panchaytai raj as self-governing institutions did not grow properly except Karnataka presumably because the other two states wanted to use these bodies as centers of power for the consolidation, expansion and enhancement of their political strength in the countryside.

\section{The Emergence of the Third Generation Panchayats}

The most significant development in the career of rural local self-government took place in 1992 when the constitutional amendments were made to empower local government in both rural and urban areas. It was a time when India opted for neo-liberal policy. These two amendments $\left(73^{\text {rd }}\right.$ and $74^{\text {th }}$ amendments) constitutionalized local governance and sought to ensure democratization of the governing processes by making it mandatory to hold elections to local bodies at regular intervals under the aegis of a constitutional body called the State Election Commission.. Added to it was the mandate for creating direct democratic institutions in the form of gram sabhas in the countryside. They clarified the status of these bodies by defining them as institutions of selfgovernment and instruments of planning for economic development and social justice. The amendments gave directions to the state legislatures, though not mandatory, to devolve powers and responsibilities to them in order to enable them to function as institutions of self-government for which it provided for the Eleventh Schedule in the Act These two amendments provide for inclusive governance by providing for reservations of seats for women and the marginalized sections of the Indian society known as the Scheduled castes and tribes. Care was also taken to strengthen the financial base of the local bodies through the setting of Finance Commission at the state level. 


\section{The Anatomy of the New Crop of Local Government}

The $73^{\text {rd }}$ Amendment was definitely a paradigmatic shift in the life of the rural local self-governance in India as it attempted to bring about a fundamental change in the governing process of rural India though the installation of the constitutionally mandated democratic institutions as supplement to the bureaucratic institutions at the district level and below. And good governance in the countryside was sought to be achieved through twin interconnected measures, namely, democratization of governance and institutionalization of participation of the villagers and empowerment of the local selfgoverning institutions.

But a close look at the processes out of which the idea emerged, would tend to show that he was primarily interested in developing an efficient delivery system in the countryside which might help in the long run to penetrate politically. Added to it were the political exigencies rooted in the political turmoil in the different parts of the country in 1970s and 1980s and considerations of power politics and compulsions of liberalization. The 1970s and 80s were marked by series of political upheavals based essentially on ethnic, religious and ethnic considerations. These movements had in fact posed a serious challenge to the legitimacy of the state. Mention may be made of the militant agitations in the North East India and in Punjab and separate state movements in many parts of the country and state autonomy movements led by the opposition ruled parties. It became evident that that the state governments were not capable of responding to these challenges effectively. Presumably, it was realized by the ruling classes that highly centralized state system was ill-suited to address the situation and thus the focus was shifted to the decentralized institutionalized arrangements. Second, the power politics of the ruling Congress Party had also necessitated it because the party was out of power in many major states. The opposition ruled states came under one umbrella to demand more powers for the states. Caught in the vortex of crisis the Indian state might have thought of empowering panchayats as an effective measure of passing the buck on the constituent states and marginalizing them at the same time by creating a direct linkage with the panchayti raj institutions through a constitutional amendment. Third, the fundamental shift in the policy by accepting liberalization has also facilitated the process of empowerment of local democratic institutions to act as their messengers in the villages and to help absorb the shocks of the policy shift. More resource mobilization for meeting some of the increasing local needs was also on the agenda. One is again reminded of the compulsions and conditions of colonial phase of strengthening local government after 1887.

\section{Democratizing Local Governance: Where the Shoe Pinches}

In this section I propose to examine some of the major impediments to democratizing governance to demonstrate how they upset the applecart of good governance. One of the primary objectives of the amendment is to democratize governance by making provision for holding of elections at regular intervals But the hopes, as the experience indicates, are belied. Some of the states have taken years to hold elections. Postponing elections under one pretext or another has become a routine matter. It is found from the grounds for the postponement of elections in Gujarat, for example, elections to panchayats have been completed in many of the states after a series of legal battles and interventions by 
the civil society organizations. In Bihar a series of legal battles led to the delay in the holding of elections. The matter was resolved finally when the Supreme Court intervened to compel the state government to hold elections pending the decision on legal issues before the court. The case of Orissa is more interesting. The elections to panchayat bodies were due to be held before February 2002. The SEC had promptly intimated the state government its preparedness to conduct elections on time and suggested delimitation of wards and reservation of seats beforehand, if required. The District Magistrate had in fact done the work. The state government had ordered limited delimitation of seats in consonance with the Orissa Gram Panchayat Act, 1964. To cause further delay in this regard the state government brought a bill in the monsoon session for the reservation of seats in favor of the Other Backward castes. The SEC chose to file a case in the High Court. At this stage the state government decided to hold elections (Panchaytai Raj Update 2003). Gujarat has recently set a unique example. The State Government has announced incentives to the extent of Rs. 1 lakh to those panchayats, which would be able to hold elections on the basis of consensus. The scheme called samras gram (harmonious village) is out and out anti-democratic. It is regarded as a recipe for reward-induced guided democracy.

In a divided society like ours, spontaneous consensus in the interest of a large section of people is a myth. If there is at all any consensus, it is that of caste, religion etc. and basically class. It is a veiled attempt to guide local democracy from the top and in the interest of the ruling classes. The Santhanam Committee (1963) examined the scope of unanimity in panchayat elections. The Committee came across villages where the anxiety for unanimity and consensus meant the continuation of the traditional authorities and suppression of the new spirit of the youth. It was felt that the securing of unanimity through cash incentives was not desirable. The silver lining is that the people of Gujarat seem to have rejected the idea as is evident from the contests that characterized the elections in more than 90 per cent of the GPs.

Interestingly, what is happening in some states in the name of achieving unanimity is a cause of serious concern. During the panchayat elections in Karnataka in 2000 some of the seats were auctioned. The Election Commission could not interfere on the ground that if the voters made an arrangement among themselves to ensure unanimous election it was beyond the legal competence of the Commission to intervene .In order to augment the resources some of the seats were put to bidding in Andhra Pradesh in 2001.Even the reserved seats were not spared. The highest amount for the post of the Sarpanch in Velpur village under Guntur district was 10.10 lakh (Mukherjee, 2008). Seats are auctioned in Madhya Pradesh and Rajasthan. In 2005, auctions were held for the post of Sarpanch in at least two gram panchayats. In Madhya Pradesh It was a case of trade off in - the post cost 1.80 lakh In Rajasthan it was the caste factor which mattered most. The panchayat dominated by the Gujjars was reserved for the SCs. Disturbed by the sudden loss of power, some of the influential Gujjar leaders decided to extract a price for the post. An announcement for open sale was made at the village chaupal (meeting place) assuring unanimous election of the highest bidder. The auction took place two weeks before the day of polling. The reserved price was fixed at Rs.50, 000. One person offered Rs.2.7 lakh and the seat was allotted to him. But the effort proved to be abortive because of the intervention of the District Collector who got three of them arrested (Panchaytai Raj Update, 2005). 
The electoral processes have been criminalized in some of the states like Uttar Pradesh (UP) Bihar. In the intermediate panchayat elections in UP there was blood bath, which resulted in the killing of 200 persons. Dalits were threatened with dire consequences. The Election Commission had to ban the entry of two ministers into their native blocks wherefrom their wives were contesting (Panchayati Raj Update, 2005). One contestant for the ZP Presidentship had 42 criminal cases against him.

There was large scale distribution of gifts and allurements offered by the candidates in UP elections held in 2005, some of them were financed by the non-resident Indian relatives. There was a free flow of money and liquor in many villages. Hand pumps were installed outside each house in one of the villages and voters in one of the villages received silver rings and glasses. A candidate in one village called Pratapgarh promised gold rings to each woman in the GP if he won. In several constituencies whisky bottles were distributed liberally. There was hardly any serious candidate who did not exceed the expenditure ceiling fixed by the SEC. The local newspapers were splashed with advertisements by the well-to-do candidates (Panchayati Raj Update, 2005).

\section{Institutionalizing Participation: The Working of Gram Sabhas}

Gram Sabha did not figure prominently in the scheme of the panchayati raj introduced in most states in early 1960s. We find from the report of the Ashok Mehta that the sporadic efforts to revive the institution were not successful due to" the lack of interest on the part of the office bearers and the apathy on the part of the public, the gram sabha has not been functioning satisfactorily."

While the constitution makes it mandatory to establish Gram Sabha at the village level, it does not stipulate any details regarding the structure, powers, and functions of this institution. In terms of Article 243G these details are to be spelt out in the panchayati raj legislations passed in each state in compliance with the 73rd amendment of the Constitution. Accordingly, all the state governments have provided for the institution of Gram Sabha in their respective panchayat legislations. But the jurisdiction of the Gram Sabha (GS) in state legislations is too big to facilitate effective participation of the people. In states like Kerala, West Bengal and Orissa the problem has been resolved by creating another body down the line at the electoral constituency level to ensure effective participation of the people (Datta, 1997; 2000).

Hardly any State Acts empower the GS to have control over the GP and to take final decisions in matters of village development. Its role is only advisory. The accountability of the GP to this body has also not been clearly spelt out in most of the state legislations. In most of the states the functional domain of the GS is limited to discussions of annual statement of accounts, administration report, and selection of beneficiaries for poverty alleviation programs. Only in a few states like Haryana, Punjab and Tamil Nadu the GSs enjoy the powers to approve the budgets.

The Gram Sabhas are yet to take off properly in almost all the states (Datta, 2006). Reports from the states indicate that the Gram Sabha meetings are not being held regularly. The Institute of Social Sciences team had found in a village in Madhya Pradesh that by December 1995, three meetings were held as against the legal requirement of six meetings.

The MP study done by Participatory Research in Asia (PRIA) group of researchers shows that majority of them did not attend meetings because the people felt that nothing 
happened at such meetings. Nirmala Buch conducted a study of 11 Gram Panchayats in MP in December 1997 and found that far from an adequate number of GS members attending the meetings even all the panchs were not (Buch, nd.) To cap it all, there was no quorum in more than 50 per cent of the GS meetings. There is a provision for mandatory attendance of one-tenth members in the Gram Sabha.

The Participatory Research in Asia team has noticed that although meetings are being held almost regularly, quorum is hardly achieved. And surprisingly, despite the lack of quorum, the proceedings are prepared. While talking to the members present in the meeting, the researchers felt that many of them were confused about the role of the Gram Sabha. Some of them perceive the Gram Sabha meetings as the political meetings and the only function of the Gram Sabha is to prepare the list of beneficiaries under the different anti-poverty programs.

An authoritative survey of panchayati raj by NIRD reports as follows: almost all the State Acts have provided for Gram Sabha but its functions have not been spelt out in detail. Consequently, these institutions by and large continue to function ineffectively, though the meetings are generally held as prescribed. The purpose is hardly served in the absence of clear and direct mandate. More often than not, there is a tendency to conduct the meetings in a formal manner and finalize the proceedings in haste. The prescribed quorum is also not given due importance. The absence of women folk in the meetings has been a common feature. The participation of the people belonging to the weaker section has been marginal. Lack of literacy makes it difficult for many to effectively voice their demands in the meetings.

But the fact still remains that in some of the States Gram Sabha meetings are generating a new atmosphere in the countryside. Social auditing at the Gram Sabha meetings has also started yielding desirable results. The Gram Sabha meeting in Karnataka successfully combated the time-honored Devdasi system, which prevailed in 167 villages of Belgaun district (Menon, 1996). The UMA Research team of Bangalore had witnessed a Gram Sabha meeting at Indore Gram Panchayat in Uttar Kanada district (UMA Prachar, nd.) . The Sabha witnessed uproarious scene when the people demanded an explanation from the secretary about the activities despite the fact a handful of members were familiar with the Act. Most of the questions were raised by the youth. The elders had hardly opened their lips.

\section{The Emerging Challenges: The MP Local Area Development (MPLAD) Scheme}

The actions taken by the Indian State after the amendment of the Constitution did not prove that there was strong political support for strengthening decentralized local governance in rural India. Mention may be made of the decision of the Indian State to introduce Members of Parliament Local Area Development (MPLAD) Scheme. Under this scheme a large sum of money per year is placed at the disposal of the MPs. The MPs are allowed to spend the money to undertake local area development schemes outside the purview of panchayats and municipalities. In this way the constitutionally mandated local government institutions are bypassed. Under the scheme each MP can suggest to the District Collector works worth up to Rs. 2 crores ( now increased to 4 crores) in a year. The Ministry releases the funds directly to the Collectors who get the 
works done on the advice of the concerned MP. The funds should be used for creation of durable assets to be vested in government. The Central Government has given an illustrative list of 28 items. There is also a list of works not permissible such as rising of memorials, building of places of worship and the like. Incidentally, the State Governments are also not lagging behind in undermining the authority of the decentralized constitutional bodies. Some of the State Governments have also introduced similar program for the MLAs.

However, the Report of the Comptroller and Auditor General (2001) showed that the MPLAD was plagued not only by the inadequacy of funds but also by the increasing underutilization, misuse and diversion of money earmarked for the project. Most of the plans undertaken form part of the $11^{\text {th }}$ and $12^{\text {th }}$ Schedules incorporated in the $73^{\text {rd }}$ and $74^{\text {th }}$ Amendments of the Constitution which clearly refer to the functions that are to be transferred to the local bodies. The Report noted that out of Rs. 5018 crores only Rs. 3221 i.e. 64 per cent of the released amount could be spent. Also, the release of funds was not linked up to their end- use, with utilization certificates being received for only $29.78 \%$ of the projects taken up and completed by the implementing agency. While during 1993-97, 89\% of the work sanctioned by the collector was taken up, only $56.13 \%$ of it could actually be completed. The corresponding percentages further declined to $86.41 \%$ and $39.42 \%$ respectively, during $1997-2000$. This was due to the fact that the Ministry often released funds without any co-relation with the end use and it did not insist on the utilization certificates from the implementing agencies.

Similar has been the findings of the sample study of audit in 106 constituencies where it was found that out of total expenditure of Rs. 265 crores reported by the Collectors, a sum of Rs. 82 crores, that is, 31 per cent of the total money was, in fact, not spent at all. The guidelines seem to have been observed more in their breach. In Nagaland, for example, the money was spent for building roads connecting the Church, in Orissa temples were built, in Madhya Pradesh money was spent for building housing complex for the police officials (Sezhiyan, 2002).

The Centre for Budget and Governance (2004) in its report, The Rhetoric and Reality of MPLADS reviews the working of the said scheme in seven constituencies spread across six Indian states- Rajasthan, Madhya Pradesh, Gujarat, Uttar Pradesh, Jharkhand and Orissa. The report holds the legislators of both the houses responsible for the underutilization of funds. While the Lok Sabha members (till 2003) used only 77\% of their total entitlement, the amount used by the Rajya Sabha members did not exceed $50 \%$.. The report also studied the scheme's beneficiaries across six states. The overall picture that emerges is that a lion's share of the MPLAD funds is spent in a top- down manner without taking into consideration people's actual needs. Beneficiaries also alleged that they were paid much less than the specified minimum wages in employment works under the scheme and an overwhelming number $(62 \%)$ agreed that the quality of assets created was either bad or very bad (Tripathi, 2004).

Some critics feel that most of the schemes being funded and executed form part of the $11^{\text {th }}$ and $12^{\text {th }}$ schedules to the Constitution which define the functional domain of the panchayats and municipalities. The guidelines authorizing the MPs to exercise their personal choice and decision in funding and executing the scheme lead to usurpation of the power and responsibilities of the local bodies. It has been argued that in many 
instances the choice of schemes and amounts expected can significantly alter or distort local priorities as may be decided or desired by the local bodies.

\section{Devolution in the Conformity Legislations}

The Eleventh Schedule does not list subjects or functions but only matters, as T.N. Srivastava (2002) pointed out. There is no constitutional mandate that rural local bodies would perform these functions or these would be transferred to rural local bodies or the schemes related to them will be entrusted to them for implementation. The legislature of a state is required to endow these bodies with such functions as may be necessary to enable them to function as institutions of self-government . Such law may contain provisions for devolution of powers and responsibilities subject to such conditions as may be specified therein and for the implementation of schemes for economic development and social justice as may be entrusted to them including those mentioned in the Eleventh Schedule. The state legislature is thus sole determinant of selfgovernment The repeated usage of the word 'may' in the Article fails to make it mandatory on the part of the state government to implement these provisions, thus leaving power- sharing with the state government solely at the disposal of the political leadership at the state level. Presumably the Parliament was compelled to use the word 'may' because some of the items come under the purview of the state list. It is also a clear indication that the Indian state lacks genuine will to create a vibrant third layer in the governance structures of the country. It is also indicative of the fact that it is not possible to strengthen the process of decentralization in India without overhauling the existing center-state relationship. Thus panchayats cannot enjoy full autonomy as they are set within the states and form part of the state list. Nor can the states for that matter as they are placed within the Indian union. What the Seventy Third Amendment has done, as Mukerjee (1994) tells us, is to constitutionalize three strata of government.

As per the information available in November 2006, only eight states and one Union territory have formally transferred all the 29 functions or subjects to the PRIs (Bryce, 2002). The Working Group on the Decentralized Planning observes, “...... items listed as responsibilities in the states are couched in vague terms. A glance at the variety of these items reveals that they are shopping list of sectors and sub-sectors, broad activities in a sub-sector and activities, sub-activities/specific responsibilities under a broad activity, with no role clarity.... In some states the line departments still exercise the powers of supervision and control over the scheme of subjects transferred to the panchayats" (The Report of the Working Group on Decentralized Planning and Panchayati Raj Institutions for the Tenth Five Year Plan (2002-2007). The Parliamentary Committee in its $37^{\text {th }}$ report submitted in 2003 expressed concern at the pace at which the states are working in this direction. The Report of the Task Force on the Devolution of Powers and Functions to the PRIs brought out by the Ministry of Rural Development has admitted that the mandatory provisions of the $73^{\text {rd }}$ Amendment Act are yet to be implemented in latter and spirit by most of the states/UTs even eight years after the said Act brought into force in April, 1993

The lack of clarity in functional allocation and absence of desegregation into detailed activities as Panchayati Raj Development Report 1995 mentions, has led to considerable overlapping and duality of control in most cases. It has been argued in the report that the functional autonomy is rendered difficult because in almost all the states, 
the state governments retain the power to assign, amend or withhold functions which as per the 73rd Amendment of the Constitution, is a job only the state governments are authorized to do.

\section{Transfer of Funds}

The transfer of functions without corresponding transfer of funds does not make sense. But this has happened. Mahi Pal rightly says that before listing the functions to be performed by the panchayats, the states have introduced certain qualifying clauses (Pal, 2004). In Andhra Pradesh, Haryana and Tamil Nadu it is "within the limits of its funds". In Punjab "it is to the extent its funds allow to perform". In Madhya Pradesh and Himachal Pradesh, it is "as far as the gram panchayat funds at its disposal".

A critical review of the provisions in the Acts of the different states regarding tax assignments, tax sharing, non- tax revenues makes it very clear that the PRIs at the level of the samiti and parishad do not have independent taxing powers. Most of the taxes are assigned at the GP levels.

The Constitution provides for setting up of the State Finance Commission (SFCs). By mid -1990 s the first SFCs had submitted their reports. Referring to the role of the SFCs the mid-term appraisal of the Ninth Plan pointed out, "more buoyant taxes like sales tax and excise are kept out of the purview of the PRIs. All SFCs have put great emphasis on internal revenue mobilization but none has suggested any effective mechanism for PRIs to generate their revenue. The SFC reports have paid less attention to issues of autonomy, financial management and auditing proceedings. The state governments have also been slow and hesitant in accepting the recommendations where they are useful in terms of improving the revenue generation capacity of the local bodies. Only two states - Karnataka and Sikkim - have devolved funds to the panchayats for 29 subjects.

A study of 15 select states, namely, Andhra Pradesh, Gujarat, Kerala, Madhya Pradesh, Maharastra, Tamil Nadu, Orissa, Punjab, Haryana, Assam, Goa reveals that where middle or top tiers have been constituted, states have not endowed them with adequate functional responsibility. Most states have granted a plethora of functional responsibilities but no executive follow up of granting adequate powers, staff and financial resources. Significantly, a study of panchayats in 15 states done by National Institute of Rural Development, shows that the political parties are reluctant to devolve powers.

\section{Transfer of Functionaries}

To function effectively as institutions of self-government the PRIs need to have the power to recruit and control staff required for managing its functions. Staff is a resource that an organization must possess to perform its activities. Strangely, Part IX and IXA of the Indian constitution remain silent on this vital aspect of institutional autonomy. Viewed from this perspective the state panchayat legislations too present an indeed gloomy picture. The state governments still have retained for themselves the power for inspection, inquiring into the affairs of the panchayats, suspension of panchayat resolutions and issuing directions. Besides in most states the key functionaries, namely, the secretaries and executive officers at all the three levels of panchayats are state 
government employees who are appointed, transferred and controlled by the state government. Being under the direct control of the state administrative hierarchy they are often reluctant to work under the administrative control of the elected panchayats. Moreover, provisions for the deputation of officials from the state government to the panchayats have been made in the state panchayat Acts without consultation with the panchayats. The tenure, transfer and the promotion of deputationists are also decided by the state government without consulting the panchayats.

\section{Centrally Sponsored Schemes}

The creation of a large number of programs (more than 200 schemes currently) called centrally sponsored schemes (CSSs) sponsored by the Union Ministries has posed a serious challenge to constitutionally mandated democratic decentralization by distorting the multilevel planning process and inter-governmental transfer arrangements within the federal set up. This is mainly because many of the subjects they deal with are either included in the State list or the 'local list' mentioned in the 11 and $12^{\text {th }}$ schedules. The share of the CSSs in the plan budget of the federal government has shot up to 70 per cent against less than 30 per cent in the early 1980s. Besides the CSSs, there are also 26 sectorial programs falling under 29 subjects of the $11^{\text {th }}$ Schedule which the central ministries handle. The schemes are drawn up at the center and implemented at the local level. The association of local bodies with the implementation processes does not really serve the purpose because the implementing bodies only implement according to the rules laid down elsewhere. The local government has to accept them because the center has financial clout.

\section{Rise of Parallel Bodies}

The emergence of a series of parallel bodies in different states has been very detrimental as they infringe on the jurisdiction of the panchayats. Broadly speaking, the functions performed by the parallel bodies can be classified as ensuring user beneficiary participation, convergence of programs and promoting efficiency. While these are the basic functions of the PRIs, the matters like irrigation, watershed management and development and minor forest produce come under the purview of the Eleventh Schedule which lays down the functions of the PRIs .The Gram Vikas Samity in Haryana and the Vigilance Committee in Himachal Pradesh, for example, encroach upon the statutory functions of the panchayat bodies as spelt out in the Panchayat Acts of the respective states. The Task Force on PRIs has argued that the Village Development Committee set up by the Government of Haryana negate the provisions of the $73^{\text {rd }}$ Amendment Act regarding reservation of SC, woman and seems to replace the elected gram panchayats. The Janmabhoomi (JB) programme in Andhra Pradesh tends to mobilize local people, the entire state administrative machinery and draws upon all the existing central and state government schemes as resource for development work and thus substitute the functions of the Gram Panchayat. Although the Sarpanch is to preside over the JB Gram Sabha, the real player is the officer. It has created another problem. The Gram Sabha meetings convened by the Gram Panchayat have become less important because of the realization on the part of the people that fewer benefits are 
available through panchayats. The Task Force on PRIs observes that it has a content of people's participation and social mobilization, but it bypasses PRIs.

It is a veiled attempt to bureaucratize rural governance Bureaucrats in local governments, especially gram panchayat secretaries, continue to exercise considerable influence over elected representatives as they are the repository of information contained in the government orders that may not be readily accessible to the elected representatives who lack an understanding of the official procedures or basic literacy skills. In Assam the co-ordination committee of the PRIs in Tinsukia district complained against the block development officers who were keeping the cheque books, ledgers and other important files with themselves (Panchayati Raj Update, 2003). In the name of control and supervision the bureaucracy has been given overriding powers over the elected panchayats in every state legislation. Such laws permit the higher echelons of bureaucracy to suspend and supersede panchayats. In a couple of states like Haryana , the Act had given the Chief Executive Officer of the Zilla Parishad the authority to refuse to implement any of its resolutions if considered by him not to be in the public interest.

There have been cases when the senior officials were found trying to thwart the role of the PRIs and curtail the power of the elected panchayats. The point has been succinctly brought out in the NIRD study. In Madhya Pradesh it was reported in the newspaper in 1996 that there were at least half a dozen cases of district level government officials being involved in brawls with the panchayat leaders. As a result of this rift the functioning of panchayats in at least 12 villages came to a halt (The Telegraph, 1996).

There is another set of parallel bodies in some states where exist traditional panchayats with different legitimizing sources. In Maharastra, for example, there exist village "collectives" called gavki The gavki is constituted by the upper caste elites, the rich and undoubtedly, only the patriachs of the village, women excluded. Before the amendment of the constitution these bodies functioned alongside the elected panchayats. Unfortunately, they continue even today. Lele narrates an interesting case of how a gavki defied the elected panchayat. The gavki decided to auction the sand from the riverbed and the money earned was to be a contribution to its own fund. The GP raised objection to it leading to a conflict situation. The persons who raised objection to this issue, were the more informed active villagers, some dalits and women, associated with a local NGO who were in favour of the panchayats However, they do not have strength to go against the gavki' The gavki has been found to be more effective in areas where women or dalits are in power. Thus, as Lele rightly observes "reservations which intended to empower both these marginalized sections in rural governance are being made ineffective by the established powers in the rural areas"(Lele, 2001).

Caste Panchayats in some states have outgrown their functions as local dispensers of justice. Recently a caste panchayat in Nauranjabad village in UP's Meerut district ruled that a young woman pregnant with the child of her second husband, return to her first husband who had reappeared after five years. The argument was that the first husband, though assumed dead, had never divorced her. Married off at just 14 to soldier Mohammed Arif Gudiya had barely spent a week with him when Arif was called to duty at Kargil War. Declared deserter by the army soon after he was given up dead as time went by. After four years 'widowed' Gudiya's parents with the consent of the 
community married her off to her cousin Tontiq. Gudiya became pregnant. Now the caste panchayat declared her second marriage illegal. The constitutional panchayat has nothing to do (Outlook, October 11, 2004).

The general reaction against the parallel bodies is that they represent processes external to the constitutionally mandated role of panchayats and enable bureaucracies to override democratic bodies. Thus, they pose serious threats to the effective functioning of local self- governing institutions.

\section{Another Mode of Bureaucratisation: District Rural Development Agencies}

The bureaucratic District Rural Development Agencies (DRDAs), which function independently of the Zilla Parishad and handle crores of rupees, should have disappeared from the scene following the 73rd amendment of the Constitution. But no such signs are visible even after more than one decade of the constitutional amendment. Instead both the Government of India and the state governments are not only continuing with them but are also adding to the list, circumscribing the powers, authority and prestige of the panchayats. The DRDAs were constituted as late as in 2002 in Goa.

Concluding Observations

It is clear that the Western liberal concept of local self-government drawing its impulse from the local areas has never been practiced in India. Local governance system during the days of the colonial rule emerged out of the economic, political and administrative compulsions of the colonial rulers. The freedom movement under the leadership of Gandhi highlighted the need for developing and strengthening rural local governance but the emotions generated died down because of the lack of objective conditions. The new ruling classes (politicians and the bureaucracy together) paid a lip service to democratic decentralization because they were essentially interested in strengthening their political support base. The first generation rural local governance failed to strike firm roots because of the inadequate political support and bureaucratic resistance coupled with socio-economic realities of rural India. The institutions imposed from the top took shape on the ground in which castism, communalism and economic inequality sharply divided the villagers. The institutions were captured by the elites who used them for distribution of patronage and domination in the villages. One can remark that colonial tradition of local governance continues unabated in post-colonial India.

The constitutional attempt to break colonial tradition in 1992 does not seem to be working properly on the ground because the threats to local democracy in rural India lie deeply embedded in Indian constitution, polity and economy (Datta, 2009). The demand for a though restructuring of the center-state relationship was first strongly put forward after the re-organization of the country in 1950s as it created contradictions between decentralized polity and centralized constitution. The Indian state had to appoint a Committee to review this issue again in 1980s but nothing substantive has emerged so far. The National Democratic Alliance government in Delhi had taken steps towards this direction but without any results. The present United Progressive Alliance government is not lagging behind but nothing visible has happened so far. All these initiatives underscore the need for a though re-examination of this aspect of the Indian Constitution as an essential step to empower local government in rural India. The Constitution was amended to strengthen local governance in rural India without resolving these basic contradictions. Local government continues to be in the state list 
but the state governments in India are very weak. Can a weak state government deliver a healthy baby of local self-government? The point was hinted at by E.MS Namboodiripad who gave a dissenting note in the Report of the Ashoka Mehta Committee. Another contradiction raised by EMS Namboodiripad relates to the distinction between regulatory and developmental functions. The panchayat bodies have been entrusted with the developmental functions but they have been given no control over the regulatory machinery of the state at the village level. This distinction weakens the base of local democratic body and retards its functioning. The constitutional amendment has not addressed this issue.

A close study of the trail of campaigns in the recent assembly elections held in 2011 tend to show that the national issues of corruption and price rise figured very prominently and results have gone the against the principal ruling party in India which has been the vanguard of liberalization. Interestingly these issues dominated the discussions in the last meeting of the National Development Council held in October, 2012. And the issue of democracy at the grassroots did not receive any attention. Against the backdrop of the larger crisis of the state local democracy seems to have taken back seat.

The fact however remains that the constitutionalization of the local governance has changed the legal status of the panchaytai raj system. Panchayati raj is no longer an idea but a practice. Elections can no longer be left to the sweet will of the ruling parties or parties at the state level, as had been the case earlier. The constitutional provisions have laid the foundation stone of local government the superstructures of which have to be built up for which what is urgently needed is spontaneous initiative on the part of the people and inter-governmental co-operation

There is some ray of hope following the rise and growth of the civil society organization in India working for democratization of governance. But the increasing attempts on the part of the political parties to capture, control and influence the working of the civil societies raises questions. Right to information has strengthened their hands. But one has reasons to be doubtful about the bright future of grassroots democracy because globalization and liberalization are hitting the "local "hard. One may argue that the current emphasis on local autonomy and resource mobilization for financing local services smacks of the colonial brand of local governance.

\section{References}

Association of Voluntary Agencies for Rural Development, 1966, Panchayati Raj as the Basis of Indian Polity, New Delhi.

Tinker, H., 1968. The Foundations of Local Government in India, Burma and Pakistha. Praeger, 1968.

Wolf, L. 1921. Life of Ripon, London, 1921 (for details, see, Prabhat Datta, The Second Generation Panchayati raj in India, Calcutta Book House, 1992).

Pal, M. , 2004. 'Panchayati Raj and Rural Governance', EPW, January 10, 2004.

Lele, M. K., 2001. 'Local Government: Conflict of Interests and Issues of Legitimisation’ $E P W$, December 22, 2001. 
Bhattarcharya, M. and Datta, P., 1991. Governing Rural India, Uppal Publishing House, New Delhi, 1991.

Mukerjee, N., 1994. 'The Third Stratum' in Renewing Local Self Governmentin Rural India , Ministry of Rural Development, Government of India, 1994.

Nirmala Buch, N., 'Women's Experience in New Panchayats: Emerging Rural Leadership', Occasional Paper No.35, Centre for Women's Development Studies, New Delhi.

Menon.' P., 1996. Sex Slaves No More: Devdasis of Belgaum District Break Free', Frontline, February 9, 1996

Partha N. Mukherjee. P. N., 2008. "Grassroots Democracy at the Cross-Roads, "Panchayati Raj Update, May, 2008.

Participatory Research In Asia 'Strengthening PRIs in India', New Delhi, 1997 unpublished.

Datta, P. (2009), The Hindu, Working Paper no. 49, 2009 , for full paper see, http//www, hpsacp.uni-hd.de see also George Mathew Threats to Grassroots Democracy, February16, 2002,

Datta, P., 1997. 'Politics at Blade and Grassroot' The Telegraph, July 10, 1997, see also Prabhat Datta, Panchayats, Rural Development and Local Autonomy; The West Bengal Experience, , Das Gupta \& Co. ,Kolkata, 2000.

Datta, P., 2006. Decentralisation, Participation and Governance, Kalpaz Publications, New Delhi, 2006.

Tripathi, P. S., 2004. 'The Case against MPLADs' Frontline, November 15, 2004.

Srivastava, T. N., 2002. Local Self Government and the Constitution' Economic and Political Weekly ( hereinafter cited as EPW), July 27, 2002.

The Report of the Working Group on Decentralised Planning and Panchayati Raj Institutions for the Tenth Five Year Plan (2002-2007) Planning Commission, New Delhi.

UMA Prachar, January-March,

The Telegraph, November 03, 1996.

Panchayati Raj Update, June 2003

Panchaytai Raj Update, August 2003

Outlook, October 11, 2004.

Panchayati Raj Update, January, 2005

Panchaytai Raj Update, January, 2005

Panchayati Raj Update, August, 2005

Sezhiyan, E., 2002. 'Development Directions' Frontline, March 15, 2002 